AGRITECH, Vol. 37, No. 4, November 2017, Hal. 402-409 DOI: http://doi.org/10.22146/agritech.10383 ISSN 0216-0455 (Print), ISSN 2527-3825 (Online) Tersedia online di https://jurnal.ugm.ac.id/agritech/

\title{
Karakterisasi Kimia dan Efek Hipoglikemik Beras Analog Berbahan Dasar Jagung, Sorgum, dan Sagu Aren
}

\section{Chemical Characterization and Hipoglycemic Effect of Rice Analogues from Corn, Sorghum, and Arenga Starch}

\author{
Slamet Budijanto', Yanica Ivory Andri ${ }^{1}$, Didah Nur Faridah¹, Santi Noviasari²* \\ ${ }^{1}$ Departemen Ilmu dan Teknologi Pertanian, Fakultas Teknologi Pertanian, Institut Pertanian Bogor, Bogor 16680, Indonesia \\ ${ }^{2}$ Program Studi Teknologi Hasil Pertanian, Fakultas Pertanian, Universitas Syiah Kuala, Banda Aceh 23111, Indonesia \\ Email: santinov.sn@gmail.com
}

Submisi: 23 Februari 2016; Penerimaan: 15 Mei 2017

\begin{abstract}
ABSTRAK
Beras analog merupakan pangan alternatif mirip beras yang dibuat dari sumber karbohidrat selain padi. Penelitian ini bertujuan untuk menentukan nilai indeks glikemik (IG) dan karakterisasi kimia (total fenolik dan serat pangan) pada beras analog berbahan baku: (1) jagung, sorgum, dan sagu aren (beras analog A); (2) jagung dan sagu aren (beras analog B). Pengujian IG menggunakan sampel darah manusia dan ditentukan dengan membandingkan luas area kurva antara sampel pangan (beras analog) dan standar ( $25 \mathrm{~g}$ glukosa) yang setara dengan $25 \mathrm{~g}$ karbohidrat. Beras analog A memiliki nilai IG sebesar 47,09, sedangkan beras analog B memiliki IG sebesar 52,31. Kedua beras analog termasuk dalam kategori pangan IG rendah. Rendahnya nilai IG dikarenakan adanya komponen fenol dan serat pangan yang terkandung pada beras analog.
\end{abstract}

Kata kunci: Beras analog; fenolik; indeks glikemik; serat pangan

\begin{abstract}
Rice analogue is an alternative food similar to rice which is made from other sources of carbohydrate apart from rice. This research was aimed to determine the glycemic index (GI) value and chemical characteristic (total phenolics content and dietary fiber) of rice analogues made from: (1) corn, sorghum, and arenga starch (rice analogue A): (2) corn and arenga starch (rice analogue B). GI was tested in human blood samples and was determined by the comparison of curve area between food sample (analogues rice) and standard ( $25 \mathrm{~g}$ glucose) which was equivalent to $25 \mathrm{~g}$ of carbohydrates. The GI values of rice analogue A and B were 47,09 and 52,31 respectively. Both were considered as low GI foods. The low GI values were due to the phenolic compounds and dietary fiber contained in the rice analogues.
\end{abstract}

Keywords: Rice analogue; dietary fiber; glycemic index; phenolic 


\section{PENDAHULUAN}

Beras tiruan atau beras analog adalah produk olahan yang berbentuk seperti butiran beras. Menurut Mishra dkk. (2012) beras analog dapat dibuat dari tepung beras pecah sebagian atau seluruhnya bahan non beras. Zhuang dkk. (2010) membuat beras analog dari beras patah (menir). Sedangkan menurut Budijanto dan Yuliyanti (2012) beras analog merupakan beras tiruan yang berbentuk seperti butiran beras yang dapat dibuat dari tepung non-beras dengan penambahan air.

Beras analog dapat dibuat dari berbagai macam bahan baku menggunakan teknologi hot extrusion. Bahan baku yang digunakan akan menghasilkan beras analog yang memiliki kandungan gizi lebih beragam. Oleh karena itu, pemilihan bahan baku harus dilakukan dengan sangat baik karena akan menentukan kandungan gizi, karakteristik fisik maupun kimia dari beras analog yang dihasilkan.

Karbohidrat yang dikonsumsi dari suatu makanan akan dicerna dan diserap oleh tubuh. Semakin tinggi atau semakin cepat daya cerna suatu pati maka semakin banyak glukosa yang dihasilkan yang menyebabkan kenaikan kadar gula darah. Salah satu penyakit yang dapat disebabkan oleh kadar glukosa darah yang terlalu tinggi adalah diabetes. Tindakan pencegahan yang dapat dilakukan diantaranya dengan memilih pangan yang tepat. Pangan yang mengandung karbohidrat yang daya cernanya lambat baik untuk dikonsumsi oleh penderita diabetes karena kenaikan glukosa darahnya lambat. Proses daya cerna setiap makanan berbeda-beda, dan dapat diketahui melalui pendekatan nilai indeks glikemik (IG).

Indeks glikemik (IG) pangan adalah sistem pengelompokan pangan berdasarkan potensinya dalam menaikkan kadar gula darah (Rizkalla dkk., 2002). Penerapan konsep IG dapat digunakan sebagai acuan dalam menentukan jumlah dan jenis pangan sumber karbohidrat yang tepat untuk meningkatkan maupun menjaga kesehatan. Pangan yang menaikkan kadar gula darah dengan cepat memiliki IG tinggi, sebaliknya pangan yang menaikkan kadar gula darah dengan lambat memiliki IG rendah (Brouns dkk., 2005). Pangan IG rendah diperlukan untuk mengendalikan rasa lapar, nafsu makan, dan kadar gula darah. Selain itu pangan IG rendah dapat membantu menurunkan berat badan (Miller dkk., 1992). Oleh karena itu pangan IG rendah tidak hanya dikonsumsi oleh penderita diabetes melitus saja tetapi juga oleh masyarakat umum untuk membantu menjaga kesehatan tubuh.

Beberapa faktor yang dapat mempengaruhi nilai IG pangan antara lain perbandingan amilosa dan amilopektin, komponen monosakarida, kadar serat, cara pengolahan pangan, ukuran partikel, kematangan, $\alpha$-amilase inhibitor, serta interaksi zat gizi dalam pati (Augustin dkk., 2002).
Penelitian yang telah menghasilkan beras analog yang tergolong dalam pangan IG rendah yaitu beras analog dari campuran jagung putih, kedelai, dan sagu dengan nilai IG 50 (Noviasari dkk., 2015) dan campuran jagung kuning, sagu, kedelai, dan bekatul dengan nilai IG 54 (Kurniawati, 2013). Nilai IG yang rendah pada beras analog dapat diperoleh karena kandungan serat pangan dan senyawa fenolik yang terkandung di dalam bahan bakunya. Serat pangan berperan dalam memperlambat kecepatan pencernaan bahan pangan dalam usus, memberikan rasa kenyang lebih lama, serta memperlambat kemunculan glukosa darah sehingga insulin yang dibutuhkan untuk mentransfer glukosa ke dalam sel-sel tubuh dan diubah menjadi energi makin sedikit. Oleh karena itu, pangan yang memiliki serat tinggi umumnya memiliki nilai IG yang rendah. Senyawa fenolik juga diketahui dapat menurunkan IG pangan melalui proses penghambatan enzim $\alpha$-amilase (Tormo dkk., 2004).

Pada penelitian ini bahan baku yang digunakan untuk pembuatan beras analog adalah jagung, sagu aren, dan sorgum. Pemilihan jagung dan sagu sebagai bahan baku karena bahan pangan tersebut sudah cukup familiar dalam masyarakat Indonesia, sehingga dharapkan beras analog yang dihasilkan dapat diterima. Selain itu jagung memiliki nilai IG 59 dalam kisaran sedang, sagu 28 (IG rendah) (FosterPowell dkk., 2002; Alfons dan Rivaie, 2011) dan jagung juga memiliki nilai serat pangan yang cukup tinggi yaitu $11,21 \%$ (Kurniawati 2013). Bahan baku lainnya yang digunakan adalah sorgum yang sangat berpotensi untuk dikembangkan menjadi bahan baku pangan fungsional, namun hingga saat ini pemanfaatannya masih sangat terbatas. Sorgum mengandung serat pangan $11,53 \%$ dan total fenolik 1,44 $\mathrm{mg} / \mathrm{GAE} / \mathrm{g}$ (Moraes dkk., 2015) yang penting sebagai bahan pangan fungsional. Kombinasi bahan baku ini diharapkan memperoleh beras analog yang memiliki nilai IG rendah, serat pangan dan konsentrasi total fenolik tinggi.

Tujuan penelitian ini adalah untuk menentukan karakteristik kimia yaitu nilai serat pangan, fenolik dan efek hipoglikemiknya yaitu nilai IG dari beras analog yang dihasilkan.

\section{METODE PENELITIAN}

\section{Bahan dan Alat}

Bahan baku yang digunakan dalam penelitian ini terdiri atas tepung jagung, tepung sorgum, dan sagu aren yang diperoleh dari F-Technopark Fakultas Teknologi Pertanian IPB. Glyceril monostearat (GMS) diperoleh dari PT. Lautan Luas Jakarta. Bahan untuk analisis proksimat meliputi heksana, $\mathrm{H}_{2} \mathrm{SO}_{4}, \mathrm{HgO}, \mathrm{K}_{2} \mathrm{SO}_{4}$, larutan $60 \% \mathrm{NaOH}-5 \% \mathrm{Na}_{2} \mathrm{~S}_{2} \mathrm{O}_{3} .5 \mathrm{H}_{2} \mathrm{O}$, $\mathrm{H}_{3} \mathrm{BO}_{3}, \mathrm{HCl}$, akuades,dan indikator metilen red-metilen blue. 
Bahan untuk analisis total fenol meliputi asam galat, etanol $95 \%$, folin ciocalteau 50\%, dan $\mathrm{Na}_{2} \mathrm{CO}_{3} 5 \%$. Bahan untuk analisis serat pangan meliputi larutan buffer fosfat $0,08 \mathrm{M} \mathrm{pH}$ 6,0, termamyl (120 L, Novo Laboratories), $\mathrm{NaOH} \mathrm{0,275} \mathrm{N,}$ amiloglukosidase (A-9913, Sigma Chemical), $\mathrm{HCl}$ 0,325 N, protease (P-3910, Sigma Chemical), etanol 78\%, etanol 95\%, aseton, dan untuk analisis uji indeks glikemik menggunakan sampel darah manusia.

Alat yang digunakan untuk pembuatan beras analog adalah Twin screw extruder (Berto BEX-DS-2256, Indonesia), disc mill, alat sosoh beras (Satake, Jepang), dan oven pengering. Beberapa alat untuk analisis yaitu Glucometer One Touch Ultra, strip analisis glukosa, lancet, kapas swab steril, spektrofotometer, sentrifus, penangas air (waterbath), penyaring vakum, crucible dengan celite, dan alat gelas lainnya.

\section{Metode}

Penelitian ini terbagi menjadi tiga tahap: (1) pembuatan dua jenis beras analog yaitu beras analog A (bahan baku jagung, sorgum dan sagu aren) dan beras analog B (bahan baku jagung dan sagu aren), (2) tahap analisis total fenolik (modifikasi Chotimarkron dkk., 2008) dan serat pangan (AOAC Official Methods 985.29 2005), (3) tahap penentuan indeks glikemik (El 1999) dua jenis produk beras analog.

\section{Formulasi Beras Analog}

Bahan baku utama dalam pembuatan beras analog adalah sumber karbohidrat yang dapat diperoleh dari umbi-umbian dan serealia non-beras. Selain itu, pati juga ditambahkan sebagai bahan perekat yang berfungsi untuk mendapatkan butiran beras yang kokoh sehingga beras tidak mudah hancur dan tidak rapuh saat dimasak (Herawati dkk., 2014). Perbandingan antara tepung dan pati dalam pembuatan beras analog adalah 70 : 30 (Noviasari dkk., 2013). Pada penelitian ini perbandingan antara tepung jagung dan sagu aren adalah $70: 30$, dan penambahan sorgum sebanyak $30 \%$ dari total bahan baku.

\section{Pengujian Nilai Indeks Glikemik}

Pengujian nilai IG dilakukan menggunakan sampel darah manusia yang seluruhnya adalah mahasiswa IPB. Sebanyak 30 orang calon relawan awalnya menjalani proses screening. Persyaratan untuk menjadi relawan pengukuran IG yaitu sehat, non-diabetes, indeks massa tubuh (IMT) dalam kisaran normal $18-25 \mathrm{~kg} / \mathrm{m}^{2}$, dan memiliki kadar gula darah puasa $60-100 \mathrm{mg} / \mathrm{dL}$. Kemudian dari proses screening tersebut terpilih 10 orang relawan yang memenuhi persyaratan.

Pengukuran nilai IG pangan diawali dengan setiap relawan harus menjalani puasa pada malam harinya (kecuali air putih) selama \pm 10 jam (mulai pukul 22.00 malam -08.00 pagi). Pagi harinya relawan diminta untuk mengkonsumsi pangan uji atau nasi analog dengan jumlah yang setara dengan 25 gram karbohidrat. Setelah itu dilakukan pengambilan sampel darah. Sampel darah yang diambil sebanyak \pm 20 $\mu \mathrm{L}$ (finger prick capillary blood sampel method) setiap 30 menit selama 2 jam (menit ke-0, ke-30, ke-60, ke-90, dan ke-120). Pengujian untuk sampel uji berikutnya dan pangan standar dilakukan pada relawan yang sama dengan jarak waktu minimal 3 hari. Pangan standar yang digunakan adalah glukosa murni sebanyak $25 \mathrm{~g}$.

Jumlah nasi analog yang diberikan dihitung berdasarkan kesetaraan dengan $25 \mathrm{~g}$ karbohidrat glukosa murni (Rimbawan dan Siagian 2004). Kesetaraan tersebut dihitung dari total karbohidrat by difference yang didapat pada analisis proksimat. Jumlah nasi yang yang akan dikonsumsi ditentukan dengan Persamaan 1.

Jumlah nasi $(g)=\frac{25 \mathrm{~g} \text { karbohidrat }}{\text { kadar karbohidrat sampel }} \times 100 \mathrm{~g}$

Pengukuran kadar gula darah dilakukan dengan alat Glucometer One Touch Ultra. Kadar gula yang ditunjukkan oleh alat uji dibuat menjadi grafik dengan sumbu X sebagai waktu pengambilan darah dan sumbu Y sebagai kadar glukosa darah, selanjutnya dihitung luas daerah di bawah kurva. Nilai yang diperoleh kemudian dibandingkan dengan luas kurva untuk pangan (glukosa murni) untuk mendapatkan nilai IG sampel dengan Persamaan 2.

Indeks Glikemik $(\mathrm{IG})=\frac{\text { luas kurva sampel }}{\text { luas kurva glukosa }} \times 100$

Nilai IG akhir adalah nilai IG rata-rata 10 orang relawan. Dari perhitungan nilai IG maka dapat diperoleh nilai beban glikemik (BG) produk. Nilai BG diperoleh dengan Persamaan 3.

Beban Glikemik $(\mathrm{BG})=\frac{\text { nilai IG } \mathrm{x} \text { karbohidrat per saji }}{100}$

\section{Analisis Data}

Data hasil penelitian disajikan sebagai $\mathrm{x} \pm \mathrm{SD}$ (rerata \pm standar deviasi). Pengolahan data analisis total fenolik, serat pangan, dan nilai IG nasi analog menggunakan uji t dengan taraf signifikansi sebesar 5\%.

\section{HASIL DAN PEMBAHASAN}

\section{Kadar Total Fenolik dan Serat Pangan Beras Analog}

Senyawa fenolik merupakan antioksidan alami yang banyak terdapat pada tanaman. Pengukuran kadar total 
Tabel 1. Kadar fenolik dan serat pangan beras analog A dan B

\begin{tabular}{cccll}
\hline \multirow{2}{*}{ Sampel } & $\begin{array}{c}\text { Total fenolik } \\
(\text { mg GAE/g } \\
\text { sampel) }\end{array}$ & \multicolumn{3}{c}{ Serat pangan } \\
\cline { 3 - 5 } & Total (\%) & Larut (\%) & Tidak larut (\%) \\
\hline Beras analog A & $0,10 \pm 0,00^{\mathrm{a}}$ & $5,22 \pm 0,16^{\mathrm{a}}$ & $2,43 \pm 0,10^{\mathrm{a}}$ & $2,80 \pm 0,09^{\mathrm{a}}$ \\
Beras analog B & $0,16 \pm 0,00^{\mathrm{b}}$ & $5,18 \pm 0,14^{\mathrm{a}}$ & $2,28 \pm 0,07^{\mathrm{b}}$ & $2,90 \pm 0,09^{\mathrm{b}}$ \\
\hline
\end{tabular}

Data disajikan sebagai rataan \pm standar deviasi; angka-angka pada kolom yang sama yang diikuti oleh huruf yang sama tidak berbeda yata pada taraf uji $5 \%$ (uji t)

fenolik kedua beras analog disajikan pada Tabel 1. Total phenolics beras analog $\mathrm{A}(0,10 \pm 0,00 \mathrm{mg}$ GAE/g sampel) dan beras analog $\mathrm{B}(0,16 \pm 0,00 \mathrm{mg} \mathrm{GAE} / \mathrm{g}$ sampel), sudah lebih tinggi dibandingkan dengan total fenol beras putih yaitu 0,044 mg GAE/g sampel (Qiu, 2009). Hal ini dapat disebabkan oleh penggunaan bahan baku jagung dan sorgum yang mengandung kadar fenolik cukup tinggi yaitu 2,6073,201 mg GAE/g sampel (De la Parra dkk., 2007) dan 1,44 mg/GAE/g (Moraes dkk., 2015), masing-masing.

Serat pangan memiliki karakteristik yang diperlukan dan dianggap sebagai unsur penting dalam formulasi makanan fungsional (Cuenca dkk., 2008). Serat pangan beras analog $(5,18 \%$ dan 5,22\%) sudah lebih tinggi jika dibandingkan dengan beras sosoh yaitu 0,19\% (Elleuch dkk., 2011). Menurut CAC (2009) makanan dapat disebut sebagai sumber serat jika mengandung serat pangan minimal $3 \%$. Sedangkan makanan disebut tinggi serat jika mengandung serat pangan minimal 6\%. Berdasarkan pernyataan tersebut maka beras analog A dan B sudah dapat dikatakan sebagai makanan sumber serat pangan.

\section{Nilai IG (Indeks Glikemik) dan BG (Beban Glikemik) Beras Analog}

Sebelum dilakukan pengujian IG, terlebih dahulu kedua beras analog dianalisis proksimat. Hal ini dilakukan untuk menentukan kadar karbohidrat beras analog sehingga dapat disetarakan dengan glukosa sebagai pangan standar pada saat pengujian IG. Pengujian proksimat dilakukan dalam bentuk nasi analog yang telah dimasak, sehingga diperoleh jumlah nasi yang akan dikonsumsi oleh relawan. Hasil analisis proksimat diperoleh kadar karbohidrat (by difference) nasi analog A adalah 29,73\% dan nasi analog B 35,32\%. Nasi analog B lebih tinggi kadar karbohidrat dan proteinnya, ini diduga karena penggunaan tepung jagung yang lebih banyak dibandingkan pada nasi analog A. Jagung merupakan komoditas serealia kedua sebagai penghasil karbohidrat $(75 \%)$ setelah beras dan juga mengandung kadar protein yang tinggi (7-12\%) sehingga dapat menjadi sumber protein yang baik (Ullah dkk., 2010). Kadar proksimat nasi analog selengkapnya disajikan pada Tabel 2.
Tabel 2. Kadar proksimat nasi analog (basis basah)

\begin{tabular}{cccccc}
\hline Sampel & $\begin{array}{c}\text { Kadar } \\
\text { air }(\%)\end{array}$ & $\begin{array}{c}\text { Kadar } \\
\text { abu } \\
(\%)\end{array}$ & $\begin{array}{c}\text { Kadar } \\
\text { protein } \\
(\%)\end{array}$ & $\begin{array}{c}\text { Kadar } \\
\text { lemak } \\
(\%)\end{array}$ & $\begin{array}{c}\text { Kadar } \\
\text { karbohidrat (\%) } \\
\text { (by diff) }\end{array}$ \\
\hline Nasi analog A & 68,42 & 0,18 & 1,43 & 0,24 & 29,73 \\
Nasi analog B & 60,55 & 0,21 & 3,68 & 0,24 & 35,32 \\
\hline
\end{tabular}

Uji IG dilakukan pada beras analog A dan B berdasarkan Ethical Approval No. LB 02.01/5.2/KE.209/2013 yang dikeluarkan oleh Komisi Etik Kementrian Kesehatan RI. Pengukuran nilai IG dilakukan dengan menggunakan 10 orang relawan yang telah memenuhi syarat-syarat pengukuran IG seperti sehat, non-diabetes, dan memiliki indeks massa tubuh (IMT) dalam kisaran normal $18-25 \mathrm{~kg} / \mathrm{m}^{2}$ serta memiliki kadar gula darah puasa $60-100 \mathrm{mg} / \mathrm{dL}$. Indeks glikemik adalah area di bawah kurva dari respon glukosa terhadap makanan yang mengandung karbohidrat dibandingkan dengan kadar glukosa standar dalam jumlah tertentu (Hallfrisch dan Behall, 2000).

Penggunaan kesetaraan 25 g merupakan modifikasi pemberian jumlah pangan uji yang akan diberikan pada relawan, yaitu setengah dari jumlah pangan uji yang disarankan (50 g karbohidrat). Hal ini tidak akan mempengaruhi respon indeks glikemik pangan jika kontrol yang digunakan mengandung karbohidrat yang jumlahnya setara dengan kandungan karbohidrat pangan uji (Venn dan Green, 2007). Berdasarkan hasil perhitungan diperoleh jumlah nasi dari beras analog A dan B yang akan dikonsumsi oleh relawan, masing-masing sebanyak 84,09 g dan 70,78 g.

Kedua nasi analog tersebut memiliki nilai IG (Tabel 3) yang sudah jauh lebih rendah dibandingkan dengan nasi putih yaitu 69 (Foster-Powell dkk., 2002). Hal ini dapat dikarenakan oleh komponen gizi yang terkandung pada beras analog. Kandungan fenolik pangan larut (Tabel 1) dapat berpengaruh pada nilai IG yang dihasilkan. Banyak faktor yang dapat mempengaruhi nilai IG suatu makanan diantaranya adalah proses pengolahan, kadar serat pangan, daya cerna pati, kadar amilosa dan amilopektin, kadar lemak dan protein, kadar gula dan daya osmotik pangan, dan kadar antigizi pangan. Selain itu jumlah konsumsi, usia serta jenis kelamin juga dapat mempengaruhi respon glukosa terhadap gula darah (Hallfrisch dan Behall, 2000).

Tabel 3. Nilai IG kedua nasi analog

\begin{tabular}{ll}
\hline Sampel & Nilai IG \\
\hline Nasi analog A & $47,09 \pm 4,79$ \\
Nasi analog B & $52,31 \pm 8,36$ \\
\hline
\end{tabular}

Data disajikan sebagai rataan \pm standar deviasi; angka-angka pada kolom yang sama yang diikuti oleh huruf yang sama tidak berbeda nyata pada taraf uji $5 \%$ (uji t) 
Senyawa fitokimia seperti fenolik merupakan antioksidan yang diketahui dapat menurunkan IG pangan melalui proses penghambatan enzim $\alpha$-amilase (Tormo dkk., 2004; Ademiluyi dan Oboh, 2013). Penghambat an kerja enzim $\alpha$-amilase oleh $\alpha$-amilase inhibitor adalah dengan cara memblok jalan masuk substrat ke sisi aktif enzim, sehingga akan menganggu daya cerna karbohidrat dan berdampak pada penurunan penyerapan kadar gula darah secara cepat (Obiro dkk., 2008). Berdasarkan sifat-sifat tersebut, senyawa fenolik yang terkandung dalam beras analog akan menurunkan daya cerna pati sehingga mengakibatkan menurunnya nilai indeks glikemiknya.

Serat pangan merupakan komponen yang tidak dapat dihidrolisis oleh enzim. Serat pangan akan membentuk matriks diluar granula pati sehingga dapat menghambat pencernaan karbohidrat (Alsaffar, 2011). Serat pangan larut diketahui dapat menurunkan respon glikemik (Elleuch dkk., 2011). Serat pangan terutama serat pangan larut memiliki kemampuan menurunkan respon glukosa darah disebabkan oleh (1) adanya peningkatan viskositas di lambung maupun intestin menyebabkan penurunan jumlah karbohidrat yang dapat dicerna (barrier terhadap enzim) dan gula sederhana yang dapat diserap, (2) serat makanan menyebabkan perubahan level hormon di saluran pencernaan, penyerapan zat gizi dan sekresi insulin, (3) serat makanan membantu meningkatkan sensitivitas insulin, menstabilkan level gula darah sehingga melindungi komplikasi akibat diabetik (Alvarez dan Sanchez, 2006). Nasi dari beras analog memiliki IG rendah juga dapat dikarenakan bahan baku pembuatannya pun memiliki IG kisaran rendah yaitu jagung memiliki IG 42 (Helmy dan ElMehiry, 2012), dan sagu 28 (Alfons dan Rivaie, 2011).

Kandungan protein juga dapat mempengaruhi nilai IG beras analog. Kandungan protein dapat membentuk matrik pangan dengan amilosa, cenderung memperlambat laju pengosongan lambung sehingga dapat menurunkan daya cerna (Alsaffar, 2011). Namun kadar protein pada nasi analog A $(1,43 \%)$ dan B (3,68\%) masih rendah dibandingkan dengan beras sosoh yaitu 7,40\% (Ohtsubo dkk., 2005). Hal ini dapat ditingkatkan dengan menggunakan bahan baku yang kaya akan protein seperti kacang-kacangan. Beras analog yang berasal dari campuran jagung putih, kedelai, sagu mengandung protein sebesar 10,48\% (Noviasari dkk., 2015), dan bahan baku jagung kuning, bekatul, dan kedelai menghasilkan beras analog dengan protein sebanyak 11,4\% (Kurniawati, 2013). Menurut Gullarte dkk. (2012) penambahan tepung kacangkacangan pada produk pangan dapat menurunkan nilai IG hingga $18 \%$. Salah satunya dapat disebabkan karena nilai IG dari kacang-kacangan umumnya rendah, misalnya kacang kedelai memiliki nilai IG 21.

Menurut Miller dkk. (1992) berdasarkan respon glikemiknya, pangan dikelompokkan menjadi 3 kelompok, yaitu pangan IG rendah ( $\mathrm{IG}<55)$, IG sedang $(55<\mathrm{IG}<$ $70)$ dan IG tinggi ( $\mathrm{IG}>70)$. Berdasarkan pengelompokan tersebut IG nasi analog A $(47,09)$ dan B $(52,31)$ termasuk kategori pangan IG rendah, dibandingkan dengan IG beras sosoh yaitu 69 (Foster-Powell dkk., 2002). Karbohidrat pada pangan yang memiliki IG rendah akan dipecah dan diabsorpsi dengan lambat, sehingga menghasilkan peningkatan glukosa darah dan insulin secara lambat dan bertahap. Pangan yang memiliki IG rendah dihubungkan dengan penurunan kejadian penyakit jantung, diabetes, dan beberapa jenis kanker (Miller, 2007; Jenkins, 2007). Selain untuk penderita diabetes, mengonsumsi pangan dengan IG rendah juga ditujukan kepada konsumen umum untuk membantu menjaga kesehatan tubuh. Hal ini karena pangan IG rendah dapat mengendalikan rasa lapar, nafsu makan, dan kadar gula darah. Selain itu pangan IG rendah dapat membantu menurunkan berat badan (Miller dkk., 1992).

Indeks glikemik memberikan informasi kecepatan perubahan karbohidrat menjadi glukosa darah, tetapi tidak memberikan informasi mengenai banyaknya karbohidrat dan dampak pangan tertentu terhadap glukosa darah. Salah satu langkah yang dapat ditempuh untuk mengetahui banyaknya karbohidrat terhadap kenaikan glukosa dapat dilihat dari beban glikemik. Beban glikemik (BG) memberikan informasi lebih lengkap mengenai pengaruh konsumsi aktual karbohidrat per saji terhadap peningkatan kadar gula darah yang ditunjukkan oleh indeks glikemik (Foster-Powell dkk., 2002).

Nilai BG berbanding lurus dengan nilai kandungan karbohidrat, yang berarti bahwa semakin tinggi kandungan karbohidrat maka semakin besar BG makanan tersebut dengan IG yang sama (Jenkins dkk., 1981). Manfaat BG didasarkan pada ide bahwa makanan dengan IG tinggi namun dalam jumlah kecil akan memiliki efek yang sama dengan makanan yang mempunyai IG rendah tetapi jumlahnya lebih banyak (Berra dan Rizzo, 2009). Kecepatan peningkatan kadar gula darah berbeda untuk setiap jenis makanan, untuk itu dianjurkan meningkatkan konsumsi makanan dengan IG rendah. Hal ini bertujuan untuk

Tabel 4. Perbandingan nilai IG dan BG beberapa jenis nasi

\begin{tabular}{cccccc}
\hline Sampel & $\begin{array}{c}\text { Karbohidrat } \\
(\mathrm{g} / \text { takaran saji) }\end{array}$ & IG & $\begin{array}{c}\text { Kategori } \\
\text { IG }\end{array}$ & BG & $\begin{array}{c}\text { Kategori } \\
\text { BG }\end{array}$ \\
\hline${ }^{1}$ Nasi merah $(150 \mathrm{~g})$ & 32,00 & 50 & Rendah & 16,00 & Sedang \\
Nasi putih $(150 \mathrm{~g})$ & 36,11 & 72 & Tinggi & 26,00 & Tinggi \\
${ }^{2}$ Nasi ketan $(156 \mathrm{~g})$ & 68,00 & 85 & Tinggi & 57,80 & Tinggi \\
$\begin{array}{c}\text { Nasi beras analog A } \\
(150 \text { g) }\end{array}$ & 29,73 & 47,09 & Rendah & 9,33 & Rendah \\
$\begin{array}{c}\text { Nasi beras analog B } \\
(150 \text { g) }\end{array}$ & 35,32 & 52,31 & Rendah & 12,31 & Sedang \\
\hline
\end{tabular}

Keterangan: ${ }^{1}$ Murray dkk. (2005), ${ }^{2}$ Soetrisno dan Apriyantono (2005) 
mengurangi BG makanan secara keseluruhan. Menurut Venn dan Green (2007) BG pangan dapat diklasifikasikan menjadi $\mathrm{BG}$ rendah $(\leq 10)$, BG sedang (11-19), dan BG tinggi $(\geq$ 20). Semakin tinggi BG maka efek kenaikan kadar gula darah akan semakin besar. Konsumsi dalam jangka panjang terhadap pangan yang memiliki nilai BG yang tinggi dapat dikaitkan dengan peningkatan resiko penyakit diabetes tipe 2 dan penyakit jantung koroner (Liu dkk., 2000).

Pada perhitungan BG nasi analog ini digunakan jumlah sajian sebanyak $150 \mathrm{~g}$ berdasarkan jumlah sajian untuk nasi putih dan nasi merah di Indonesia pada umumnya (Regina, 2012). Pada takaran saji 150 g nasi analog A memiliki BG rendah yaitu 9,33, sedangkan nasi analog $\mathrm{B}$ memiliki $\mathrm{BG}$ sedang yaitu 12,31 (Tabel 3). Nasi analog memiliki BG yang lebih rendah jika dibandingkan dengan nasi putih yang memiliki BG 26 (kategori tinggi). Hal ini menunjukkan konsumsi nasi analog pada jumlah yang sama dengan nasi putih akan lebih lambat menaikkan kadar glukosa darah.

\section{KESIMPULAN}

Beras analog A dan B memiliki konsentrasi total fenolik yang cukup tinggi yaitu $0,10 \mathrm{mg}$ GAE/g sampel dan $0,16 \mathrm{mg}$ GAE/g sampel (masing-masing). Kedua beras analog tersebut juga dapat dijadikan sebagai sumber serat pangan dengan kadar 5,22\% (beras analog A) dan 5,18\% (beras analog B). Komponen gizi tersebut mengakibatkan rendahnya nilai IG beras analog A dan B berturut-turut yaitu 47,09 dan 52,31, sehingga termasuk ke dalam pangan IG rendah. Pada takaran saji 150 g nasi analog A memiliki BG rendah $(9,33)$ dan nasi analog B memiliki BG sedang (12,31).

\section{DAFTAR PUSTAKA}

Ademiluyi, A.O. dan Oboh, G. (2013). Soybean phenolic-rich extracts inhibit key-enzymes linked to type 2 diabetes ( $\alpha$-amylase and $\alpha$-glucosidase) and hypertension (angiotensin I converting enzyme) in vitro. Journal Experimental and Toxicologic Pathology 65: 305-309. doi: 10.1016/j.etp.2011.09.005.

Alfons, J.B. dan Rivaie, A.A. (2011). Sagu mendukung ketahanan pangan dalam menghadapi dampak perubahan iklim. Jurnal Perspektif 10(2): 81-91.

Alsaffar, A.A. (2011). Effect of food processing on the resistant starch content of cereals and cereal products - a review. International Journal Food Science and Technology 46: 455-462.

Alvarez, E.E. dan Sanchez, P.G. (2006). Dietary fiber.Journal Nutrition Hospital 21(2): 60-71.
Association of Official Analytical Chemist (AOAC). (2005). Official Methods of Analysis of The Association of Official Analytical Chemist. AOAC Inc., Arlington(VG).

Augustin, L.S., Franceschi, S., Jenkins, D.J.A., Kendall, C.W.C. dan Vecchia, C.L. (2002). Glycemic index in chronic disease: a review. European Journal Clinical Nutrition 56: 1049-1071.

Berra, B. dan Rizzo, A.M. (2009). Glycemic index, glycemic load, wellness and beauty: the state of the art. Journal Clinical Dermatology 27: 230-235.

Brouns, F., Bjorck, I., Frayn, K.N., Gibbs, A.L., Lang, V., Slama, G. dan Wolever, T.M.S. (2005). Glycaemic index methodology. Nutrition Research Reviews, Journal ProQuest Agriculture 18: 145-171. doi: 10.1079/ NRP2005100.

Budijanto, S. dan Yuliyanti (2012). Studi persiapan tepung sorgum (Sorghum bicolor L. Moench) dan aplikasinya pada pembuatan beras analog. Jurnal Teknologi Pertanian 13(3): 177-186.

Codex Alimentarius Commission (CAC). (2009). Alinorm 09/32/26. Appendix II. Report of the $30^{\text {th }}$ Session of the Codex Committee on Nutrition and Foods for Special Dietary Uses [Internet]. [Cape Town, South Africa 3-7 November 2008]. Rome (IT): FAO. hlm 46. http:// www.codexalimentarius.net/dowload/report/710/ al32_26e.pdf. [15 September 2014].

Chotimarkron, C., Soottawat, B. dan Nattiga, S. (2008). Antioxidant component and properties of five long grained rice bran extracts from commercial available cultivar in Thailand. Journal Food Chemistry 111: 634 641.

Cuenca, A.R., Suarez, M.J.V. dan Aparicio, I.M. (2008). Soybean seeds and its by-product okara as sources of dietary fibre. Measurement by AOAC and Englyst methods. Journal Food Chemistry 8: 1099-1105. doi:10.1016/j.foodchem.2007.11.061.

De la Parra, C., Serna-Saldivar, S. dan Liu, R.H. (2007). Effect of processing on the phytochemical profiles and antioxidant activity of corn for production of masa, tortillas, and tortilla chips. JournalAgriculture and Food Chemistry 55: 4177-4183.

El, S.N. (1999). Determination of glycemic index for some breads. Journal Food Chemistry 67: 67-69.

Elleuch, M., Bedigian, D., Roiseux, O., Besbes, S., Blecker, C. dan Attia, H. (2011). Dietary fibre and fibre-rich by-products of food processing: Characterisation, technological functionality and commercial 
applications: A review. Journal Food Chemistry 124: 411-421. doi:10.1016/j.foodchem.2010.06.077.

Foster-Powell, K.F., Holt, S.H.A. dan Miller, J.C.B. (2002). International table of glicemic index and glycemic load values. American Journal of Clinical Nutrition 76: $5-56$.

Gullarte, M.A., Gomez, M. dan Rossel, C.M. (2012). Impact of legume flours on quality and in vitro digestibility of starch and protein from gluten-free cakes. Journal Food Bioprocess Technology 5(8): 3142-3150.

Hallfrisch, J. dan Behall, K.M. (2000). Mechanisms of the effects of grains on insulin and glucose responses. Journal of the American college of Nutrition19(3): 320S-325SS.

Helmy, H. dan El-Mehiry, H. (2012). Effect of egyptian bread prepared by different types of flour on diabetic rats and its glycemic index in diabetic patients. Journal Life Science 9(3): 2264-2272.

Herawati, H., Kusnandar, F., Adawiyah, D.R. dan Budijanto, S. (2014). Teknologi proses produksi beras tiruan mendukung diversifikasi pangan. Jurnal Litbang Pertanian 33(3): 87-130.

Jenkins, D.J.A., Wolever, T., Taylor, R.H., Barker, H., Fielden, H., Baldwin, J.M., Bowling, A.C., Newman, H.C., Jenkins, A.L. dan Goff, D.V. (1981). Glycemic index of foods: a physiological basis for carbohydrate exchange. Americal Journal of Clinical Nutrition 34: 362-366.

Jenkins, A.L. (2007). The glycemic index: Looking back 25 years. Journal Cereal Foods World 52: 50-53.

Kurniawati, M. (2013). Stabilisasi Bekatul dan Penerapannya pada Beras Analog. Tesis. Fakultas Teknologi Pertanian. Institut Pertanian Bogor, Bogor.

Liu, S., Willet, W., Stampfer, M., Hu, F., Franz, M., Sampson, L., Hennekens, C. dan Manson, J. (2000). A prospective study of dietary glycemic load, carbohydrate intake, and risk of coronary heart disease in US women. American Journal Clinical Nutrition 71: 1455-1461.

Miller, J.B., Pang, E. dan Bramall, L. (1992). Rice: A high or low glycemic index food?. American Journal Clinical Nutrition 56: 1034-1036.

Miller, J.B. (2007). The glycemic index as a measure of health and nutritional quality: An Australian perspective. Journal Cereal Foods World 52: 41-44.

Mishra, A., Mishra, H.N. dan Rao, P.S. (2012). Preparation of rice analogues using extrusion technology. International Journal Food Science Technology 47: 1789-1797. doi:10.1111/j.1365-2621.2012.03035.x.
Murray, M., Pizzorno, J. dan Pizzorno, L. (2005).The Encyclopedia of Healing Foods. Time Warner Books, USA.

Noviasari, S., Kusnandar, F., Setiyono, A. dan Budijanto, S. (2015). Beras analog sebagai pangan fungsional dengan indeks glikemik rendah. Jurnal Gizi Pangan 10(3)225232

Noviasari, S., Kusnandar, F. dan Budijanto, S. (2013). Pengembangan beras analog dengan memanfaatkan jagung putih. Jurnal Teknologi dan Industri Pangan 24: 195-201. doi: 10.6066/jtip.2013.24.2.195.

Obiro, W.C., Zhang, T. dan Jiang, B. (2008). The nutraceutical role of the Phaseolus vulgaris $\alpha$-amylase inhibitor. British Journal of Nutrition 100: 1-12.

Ohtsubo, K., Suzuki, K., Yasui, Y. dan Kasumi, T. (2005). Biofunctional components in the processed pre-germinated brown rice by a twin-screw extruder. Journal of Food Composition and Analysis 18: 303-316.

Qiu, Y. (2009). Antioxidant Activity of Commercial Wild Rice and Characterization of Phenolic Compounds by HPLC-DAD-ESI-MS/MS [tesis]. Ottawa (CA): University of Manitoba.

Regina (2012). Daftar indeks glikemik makanan. http:// diabetesmelitus.org. [20 Maret 2014].

Rimbawan dan Siagian, A. (2004). Indeks Glikemik Pangan. Jakarta (ID) : Penebar Swadaya.

Rizkalla, S.W., Bellisle, F. dan Slama, G. (2002). Health benefits of low glycaemic index foods, such as pulses, in diabetic patients and healthy individuals. British Journal of Nutrition 88(3): 255-262. doi: 10.1079/ BJN2002715.

Soetrisno, U.S.S. dan Apriyantono, R.R.S. (2005). Formula Karbohidrat dan Protein Terolah untuk Makanan Jajanan Glikemik Tinggi. Prosiding Temu llmiah Kongres Xlll PERSAGI 2005 Denpasar Bali, pp. 349 : 352 .

Tormo, M.A., Exojo, I.G., Tejada, A.R. dan Campillo, J.E. (2004). Hypoglycaemic and anorexigenic activities of an $\alpha$-amylase inhibitor from white kidney beans (Phaseolus vulgaris) in Wistar rats.British Journal of Nutrition 92: 785-790. doi: 10.1079/BJN20041260.

Ullah, I., Ali, M. dan Farooqi, A. (2010).Chemical and nutritional properties of some maize (Zea mays L.) varieties grown in NWFP. PakistanJournal of Nutrition 9(11): 1113-1117. 
Venn, B.J. dan Green, T.J. (2007). Glycemic index and glycemic load: measurement issues and their effect on diet-disease relationships. European Journal Clinical Nutrition 61(1): 122-131. doi: 10.1038/sj.ejcn.1602942.
Zhuang, H., An, H., Chen, H., Xie, Z., Zhao, J., Xu, X. dan Jin, Z. (2010). Effect of extrusion parameters on physicochemical properties of hybrid indica rice (type 9718) extrudates. Journal of Food Processing and Preservation 34: 1080-1102. 